\title{
Russian Legal System in the Context of the Transitive Society
}

\author{
Gennady Nebratenko, Svetlana Studenikina*, Olga Kazantseva and Tatyana Moskaleva \\ Don State Technical University, department «Procedural Law», 344000 Rostov-on- Don, \\ Russian Federation
}

\begin{abstract}
In the context of the transitive society building one emphasizes the significance of the tendencies and perspectives of the development of legal and regulatory framework of the national policy in the sphere of education which, as well as the law, is a part of the social system, and the national legal system is the constituent element of the latter. This fact correlates with the problems of the Russian law system and transitional society that are considered in this article.
\end{abstract}

\section{Introduction}

The characteristics of the modern Russian legal system make it correspond to the Romano- Germanic legal family; at least this point of view is accepted in comparative legal studies. This means that Russia, being an international legal entity, has rejected the normative regulatory organization which has been characteristic for it during its previous thousand- year history. The rejection of traditionalism, conservative approach that is characteristic for, for example, the national legal development of Great Britain took place twice during the $20^{\text {th }}$ century predetermining the change of the form of the state and the social and political formation (in 1917 and 1991). So, the absence of political stability as the characteristic of the national legal development is of itself traditional for the Russian state in contemporary history. Though it was the traditionalism of the policy of grand dukes, tsars and Russian emperors that made it possible for the Riurikids and Romanovs to create the biggest multinational state which was transcontinental up to 1867 under the conditions of tough competition. Both this potential and the results of the World War II let Russia stay one of the leading international legal entities that can express their own independent opinion in the international context even after the political upheavals that shook the foundations of its state system in the $20^{\text {th }}$ century.

\section{Results and discussion}

\footnotetext{
* Corresponding author: kazantseva10@mail.ru
} 
It is obvious that the key element of the national legal system is the society itself and the social relationships on the harmonization of which the mechanism correlating the legal system, law practice and legal awareness works. Modern Russian society, as well as the society of any developed state, is characterized by the urge towards transitivity but in Russia this urge correlates not only with the transformation of the industrial relationships into post-industrial, i.e. informational, ties, but it is also loaded down with the preceding collapse of the Soviet Union and the loss of the primacy of its own nationalmentality.

The experience of the People's Republic of China which demonstrates the best indicators of social and economic growth shows that the Russian state too early refused

from the multisectoral economy. The possibilities brought by the combination of socialistic organization and capitalistic stimuli were not quite exhausted, so one can not consider the loss of the USSR progressive for the peoples that lived in it. So, if the characteristic for the information-oriented society deindustrialization tendency in the capitalist states and the transfer of production facilities to the countries of the third world because of the low-cost labour force and the proximity to the resource base were quite natural, the specific character of post-Soviet Russia is determined by the decline in national capacities, unemployment and impoverishment of wide sections of the population. It was likely that the resulting shortage of goods would be offset by imports but few people could acquire them in the conditions of the raw materials and rent-raw materials economy and the characteristics of the redistribution of surplus product. As a result, the problems of transitivity in Russia are of transitional character determined by the destruction of a centralistic political system, previous collapse of the socialist principle of distribution of material goods and the lack of clear spiritual, moral, political and legal priorities for at least the next decade.

The transition of the Russian legal system to the Roman-Germanic family of law is a difficult choice since from a civilizational point of view, continental Europe itself is under the influence of the Anglo-Saxon culturological tradition. After all, the interaction of law, legal practice and legal consciousness not only provides legal regulation of social relations, but also characterizes the level of development of the legal culture, and the latter is a part of culture in general. Therefore, having recognized the superiority of Romano-Germanism, Russian society not only created prospects for the degradation of the national mentality, but also simultaneously got connected to the liberal trends of the Anglo-Saxon world. Of course, these trends are also explicated in law, being expressed, for example, in the absence of a clearly defined system of law (branches of law) in Great Britain, the lack of classification for private and public, substantive and procedural law, and the inexpediency of formulating normative legal acts at a high level of legal technique, since the judicial precedent is the main form of law, and, finally, in the absence of constitution! It is obvious that such signs are unthinkable for the national legal systems of the Romano-German legal family, including the Russian Federation. Meanwhile, there is no guarantee that "pseudo- European values" are acceptable to our Fatherland as they modernize the public consciousness, of which the legal consciousness is a structural part.

The concept of a transitive society is also an innovation, being instilled, as in the past, gender theory or the principles of tolerance, partly multiculturalism were. At the same time, it is likely that new trends are being delivered to continental Europe hardly for its prosperity, rather for strengthening the existing system of transcontinental redistribution of resources and goods, while money is the metrological equivalent of goods turnover.

At the same time, the revival of national political economic thought does not contradict the construction of a transitive society, which will have a chance to develop 
according to the norms and principles that are supplied by such society and suitable for working out a development strategy, which Russian President Vladimir Putin spoke about in his annual Address to the Federal Assembly of the Russian Federation on February 20, 2019. The head of the state noted that one should "focus primarily on issues of internal social and economic development. And to pay special attention ... to the tasks that have been set in the May decree, posed in national projects. Their content and guidelines reflect the needs and expectations of the citizens of the country. National projects are built around a person in order to achieve a new quality of life for all generations, which can only be supported on condition of the dynamic development of Russia. Our tasks are of long-term character... We must only move forward, constantly gaining momentum in this movement" [1]. In this regard, it is obvious that the idea of building a transitive society is on the list of priorities for building a modern Russian state, it seems interesting, deserving doctrinal attention and requiring legal reflection, including using the tools of Comparative Law.

The concept of the legal system of society is structured in such a way that by illustrating the paradigm of the legal regulation of social relations, the possibility of improving legal reality opens up, and the incorporation of segments of a transitive society in this sense is no exception. However, reforms should be carried out very cautiously and carefully so as not to unbalance the mechanism of "checks and balances" that has been developed in the state, as it happened in 1986-1991.

Not only technical and legal means, but also ideological tools are suitable for improving the national legal system, while one should not avoid criticism and believe in the boast of the unconditional acceptability of humanitarian innovations brought by Western scientific thought into contemporary Russian reality. Especially taking into account the fact that reform activity has been carried out in modern Russia since 1991, and the endlessness of radical transformations forms skepticism in the society regarding them, making the evolutionary theme of the development of socio-political processes more acceptable. In addition, in the context of the experiment on the construction of a transitive society in Russia, it should be remembered that the domestic legal system, although it belongs to the family of Romano-German law, is hybrid, like of most states in the modern world.

What is meant by the "hybridity" of the Russian legal system? The latter, according to the authors, is a symbiosis of three legal traditions that take place on the legal map of the world: Romano-Germanic, religious and socialist. The fact that the Russian legal system, by its characteristics, is a part of the family of Romano-German law, has been discussed above and this does not require argumentation, but two other views are associated with the atavism of the previous forms of state organization. For about 1000 years, the Russian state has been a monarchy, and the paternalistic trend of public consciousness that has arisen in this regard is part of the Russian "ethnic code", transmitted on a psycho-emotional, social- normative and even genetic levels. In 988, Ancient Rus' adopted Christianity and until 1917 the Russian Orthodox Church was synchronized with the state, officially fulfilling part of its functions, for example, registering acts of the civil status, advancing spiritual and moral education, stimulating demographic reproduction (growth) of the population, spreading primary education. In this regard, the legal consciousness of the Russian people is still determined by Christian morality and the commandments of the prophet Moses. The domestic worldview is permeated with the dogmas of Orthodoxy (for devout believers) or its atavisms (for the laity or unbelievers who recognize the church). At the same time, legal consciousness is one of the three main elements of the legal system of society, and the remaining parts: law and legal practice are developed taking into account the third one, since they are all correlated with each other, allowing for legal regulation of public relations, specifying 
the content and the level of the development of legal culture [3].

The hybridity of the Russian legal system, associated with the atavisms of the signs of the family of socialist law, also has specific historical prerequisites determined by the fact that from 1917 to 1991 Russia existed in the form of the Soviet state. To this day, individuals who have undergone legal education on the basis of materialistic legal understanding live in the Russian Federation and beyond its borders, they are also intellectual carriers of the values of socialism, even when they deny it. So far, in domestic legal reality, there are facts of primacy of moral incentives, for example, in the field of labor law, such as annual subbotniks (voluntary Saturday work), full-time wages below the subsistence level, unpaid overtime work, which have nothing to do with a developed capitalist society, all these interfere with the formation of transitivity in the Russian society. Such "isolated cases of overzealous bureaucracy" are possible only because stereotypes of the socialist worldview are triggered at the psychoemotional level, when personal interests are pushed into the background, and the public ones dominate. Meanwhile, in the Soviet legal system, excluding the NEP period (19211929), all forms of human exploitation by man were prohibited, and "unpaid overtime work" was carried out in favor of the state, and in modern Russian society, individuals are the "consumer of the benefits" from violation of labor rights.

The construction of a transitive society inevitably takes place in the conditions of modern Russian reality, but in reality it turns out to be even more multivalent than it was previously noted. The Russian legal system is included in the group of Slavic legal systems, which clarifies the internal structure of the Romano-Germanic legal family, but on the other hand, pan-Slavism and the Russian idea in the public consciousness, of which the legal consciousness is a part, are generally regarded as an anachronism [2]. At the same time, the idea of ensuring the rights of national minorities is being cultivated, the largest of which have sovereignty within the framework of the Russian Federation (republics within Russia). At the same time, the number of Russian and Russianspeaking population in the Russian Federation exceeds the share of all titular nations taken together, but this fact is not reflected in the current legal ideology. In addition, historically, the founder of the Russian state is the Russian people. However, Russia is an asymmetric federation, and ensuring the political rights of national minorities prevails over the realization of the socio-economic rights of the multinational people of the Russian Federation. From the point of view of political and economic feasibility, the administrative-territorial structure of our state can undergo changes due to the enlargement of some entities, for example, the Republic of Adygea and the Krasnodar Krai, which, according to economic and geographical characteristics, are a part of a single whole (space).

\section{Conclusions}

Thus, the construction of a transitive society in Russia should take into account a whole number of factors related to specific historical, national, religious, political and socioeconomic peculiarities of the formation and development of the domestic national legal system. In the process of construction of a transitive society particular attention should be paid to legal awareness as one of the main elements of the legal system of society. Legal consciousness is an anthropological element of social and legal reality that directly affects the experience of legal regulation of public relations.

In this regard, one should not forget about legal education, which can take into account the models and principles of a transitive society, and for this it is necessary to determine the psychological and pedagogical trends of transitivity, adaptable to the realities of the modern Russian life. 


\section{References}

1. V. V. Putin, Message from the President of the Russian Federation to the Federal Assembly of the Russian V Federation (Moscow, 2019)

2. V. Lafitsky, Comparative jurisprudence in the images of law (Moscow, 2010)

3. G. Nebratenko, The history of comparative law in Russia. Russian law: theory and practice (Moscow, 2016) 